\title{
Iranian EFL Instructors' Educational and Professional Backgrounds and Their Awareness of Assessment Strategies and Teaching Skills
}

\section{${\text { Masoumeh Ghavidel }{ }^{1} \& \text { Valeh Valipour }}^{1 *}$}

* Correspondence:

masoum.ghavidel@yahoo.com

1. Department of English Language,

Tonekabon Branch, Islamic Azad

University, Tonekabon, Iran

Received: 25 July 2021

Revision: 15 September 2021

Accepted: 21 October 2021

Published online: 20 December 2021

\begin{abstract}
Within the framework of professional development, teachers adapt, develop, and complement their pedagogical competences and behavior, and they become an agent of change. In this regard, teachers' awareness of the components of pedagogical competence plays an important role. The current paper addressed the components of assessment strategies and teaching skills and investigated Iranian university instructors' awareness of these components with regards to their personal, professional, and educational backgrounds. In so doing, a 29-item questionnaire already established in terms of validity and reliability was administered to 72 university instructors practicing teaching in Guilan universities. Analysis of the results revealed that the instructors used different assessment strategies and employed various teaching skills with regard to their gender, teaching experience, fields of study, and university degrees. The results may be practically utilized by education authorities to provide instructors with appropriate trainings to augment the instructors' teaching and learners' learning in the end.
\end{abstract}

Keywords: pedagogical competence, assessment strategies, teaching skills, EFL instructors, personal, professional, educational backgrounds 


\section{Introduction}

Within the context of restructuring Iranian system of education, many attempts have been made to improve the educational standards with regard to Teaching English as a Foreign Language (TEFL) context and the English as a Foreign Language (EFL) learners' language learning in an outcome-based approach that can identify and fulfill their needs through teaching and observing their learning processes. According to Nenty, Adedoyin, Odili, and Major (2007), education has a positive impact on the behavior of learners, the quantity and quality of which can only be identified by actual assessment practices.

The awareness of assessment strategies as one of the important components of teachers' pedagogical competence serves multiple functions, such as providing information about the learners' learning progress and achievements, quality of teaching, and the accountability of programs (Fletcher, Meyer, Anderson, Johnston, \& Rees, 2012). Public education across the world has always been witnessing growing concerns with improving assessment practices, indicating that proper and feasible methods of assessment play a vibrant role in accomplishing the objectives of any education. Classroom assessment practices are crucial facets of effective teaching and learning process (Bloxham \& Boyd, 2007). According to Linn and Miller (cited in Movahedi \& Aghajanzadeh Kiasi, 2021), assessment of student learning is a systematic process of collecting information about student progress towards the learning goals. In addition, Smimou and Dahl (2012) define assessment methods as "teaching practices employed to know how well a student has been performing in his learning process" (p. 21).

On the other hand, the objective of any instruction is to guarantee learning, and if learning does not transpire, the objective is not achieved. For Shukla (2007), teaching is "transferring or conveying knowledge, attitudes, and skills" (p. 32), and for Soga (2000), it is "a planned appointment between the teacher and the learner over a given subject matter in order to bring about learning using appropriate methods and materials in a moderately conducive venue" ( $\mathrm{p}$. 12). According to Ayua (2017), teaching includes all the processes and activities that are intended to convey knowledge and skills at all stages of education.

Therefore, teaching in which learning is the main outcome is the standard of teacher-student interactional contact. Fundamentally, a teacher guides the activities done by students in order to produce learning in direct, indirect, structured, and unstructured ways. Skills of teaching, which lie at the central part of pedagogical competence, are verified in the ability of a teacher to teach in a way that it dynamically supports students' learning. However, as Ryegard, Apelgren, and Olsson (2010) note, certain situations impose limitations on teaching skill, and teachers do not necessarily have to make conscious didactical choices in order to succeed because teaching skill does not solely provide a basis for accomplishing pedagogical competence. Thus, as Jay and O'Conner (2005) argue, the skills of teaching refer to teachers' classroom practices shaped by a wide range of interacting factors mediated by teaching methods that functionally support students' learning.

One general objective of the present study was to shed light on the status of the concepts of the needed competences for effective teaching among the instructors at university level. In addition, the second, but more specific objective of the present study was to know the differences in the instructors' professional and personal backgrounds with regard to their skills of teaching and assessment. Thus, the research could shed light on the relationship between the factors and the related competence. So, this study intended to investigate the relationship between the Iranian EFL university instructors' characteristics of gender, age, fields of study, and university degrees with the pedagogical components of teaching skills and assessment strategies.

\subsection{Statement of the Problem}

Pedagogical competence for English language teachers is highly critical. This requires more qualified teachers who need to be able to manage a broader range of teaching and to meet the diverse learners' needs. To fulfill this issue, effective English language teachers are obliged to look carefully and continuously at their teaching practice in order to improve their pedagogical competence so as to develop an outcome-based teaching practice. One of the issues that is not paid attention to in the Iranian context is English teachers' attitudes about teaching, learning, their role, all of which, according to researchers (Feiman-Nemser, 2008; Zeichner \& Liston, 1996), affect the way teachers choose, evaluate, and comprehend the knowledge acquired, as well as the way they benefit from this knowledge in practice, as this very practice is shaped by that knowledge.

Similarly, although it is quite known that the attitudes of teachers affect their degree of commitment to their duties, the way they teach and treat their students, as well as how they perceive their pedagogical growth (Chen, Wu, \& Liu, 
2015; Darling-Hammond, 2000), teacher's attitude has not been paid attention to in recent studies, to the best of the researchers' knowledge, especially at higher education level. This construct finds its importance specifically when teachers have high expectations for their students and insist on promoting learning for all students (Malikow, 2006; McBer, 2000). Teachers need to have critical, evidence-based attitudes to their own practices, grounded in input from different sources (McLaughlin \& Talbert, 2001).

Within the same lines, Bell (2005), adopting a Likert-scale questionnaire, studied the attitudes and behaviors of 457 foreign language teachers of German, French, and Spanish. The study gave prominence only to the attitude of teachers not the other constructs and features of skillful teachers. In the meantime, Soodmand Afshar and Doosti (2017) investigating the effective EFL teachers from both teachers' and students' perspectives, found that both teachers and students stressed teachers' professional qualities (e.g., subject matter knowledge, ability to impart knowledge, etc.). However, their research did not account for all the teachers' quality such as teaching skills, and assessment ability.

Most importantly, there exists no clear-cut criterion based on which the teachers' pedagogical competence can be measured, and the required standards to check the teachers' existing perceptions and teaching practice are missing in the Iranian EFL setting. Additionally, there are other problems and reasons why a new study is really felt and needed. The importance of an adequate knowledge base for teaching has not been recognized and received much emphasis. These problems and the other problematic issues justify any kind of related research in the area under the question, and the present study is an attempt to shed light on these important issues.

\subsection{Research Questions}

In line with the points mentioned above with regard to the Iranian university EFL instructors' awareness of assessment strategies and skills of teaching, the present study explored the degree of difference between instructors' personal, pedagogical, and professional backgrounds and their teaching experience, fields of study, university degrees, and gender. Therefore, the study posed two questions:

Is there any statistically significant difference between the instructors' teaching skills and their gender, teaching experience, fields of study, and university degrees?

Is there any statistically significant difference between the instructors' assessment strategies and their gender, teaching experience, fields of study, and university degrees?

\subsection{Research Hypotheses}

According to the research questions mentioned above, the following research hypotheses were proposed for the current study:

There is not any statistically significant difference between the instructors' teaching skills and their gender, teaching experience, fields of study, and university degrees.

There is not any statistically significant difference between the instructors' assessment strategies and their gender, teaching experience, fields of study, and university degrees.

\section{Literature Review}

Educators have always viewed assessment as a means of evaluation tool for measuring learning outcomes, and this has been materialized through summative assessment (Popham, 2008). However, educators have begun to broaden their scope of assessment knowledge to cover students' learning outcomes to make passing or failing decisions and enhance students' learning by adjusting classroom instruction (Wilson \& Sloane, 2010). This is exactly what assessment for learning (AfL) functions as it targets to improve teaching quality and adjust assessments results to improve students' learning.

Since well-established methods of assessment have positive impacts on students' learning, education institutions are persistently urged to use effective assessment methods that mutually augment the learning and teaching process (Alquraan, 2012). Therefore, appropriate assessment methods and learning outcomes are aligned because, as Brookhart and Nitko (2008) note, no individual assessment method is able to address the learning progress and outcome. It is clear that multiple assessment types provide students with many opportunities to disclose their learning levels. 
Exploring school teachers' literacy levels of classroom assessment and their awareness of assessment strategies, Yamtima and Wongwanichb (2014) carried out a study in which 19 school teachers completed a questionnaire of classroom assessment literacy and strategies. The results of their study revealed that the teachers' classroom assessment literacy lied at a poor level, and their awareness of assessment strategies was very limited to a few kinds. The researchers suggested an approach to improving the classroom assessment literacy and strategies of the teachers in cooperation and teamwork.

With regard to teachers' receiving of training in assessment strategies, a survey of Morocco national exams carried out by Melouk (2016) showed that little change has been produced in the way exams are designed. The results of his study displayed that a few number of teachers have received a limited training in assessment while majority of teachers expressed their interest for training in item production and management. In the same line, utilizing questionnaires and interviews, Khtou (2011) probed students' and teachers' attitudes toward assessment in Morocco. Both teachers (60\%) and students $(63 \%)$ indicated that the assessment system was poor and asked for a system that would be able to provide teachers and students with appropriate feedback on their work to help them improve teachers' teaching practice and students' learning. They expressed that there was no room for improvement, and there were most likely the same mistakes continuing to appear in new situations very strongly.

In an EFL context like Iran where the curriculums are profoundly prescribed, and high-stake national exams are compulsory, there may be very little space for innovative practices. However, according to Brečko, Kampylis, and Punie (2014) and Shimasaki (cited in Lucas, 2018), a proper top-down support at policy level would only facilitate the administration of assessment practices that could be flexible and innovative. Innovative assessment would be sustainable if it relies heavily on a working group monitoring which requires the coordination of all stakeholders (Ávila, Filho, Brandli, Macgregor, Molthan-Hill, Özuyar, \& Martins, 2017). Most importantly, the educational innovation needs to be clearly valued, communicated, and supported at policy level. If educators' initial and continuous training are invested on, their professional development will be on going and will never terminate (Broadfoot, Timmis, Payton, Oldfield, \& Sutherland, 2013; Lucas, 2018).

Traditionally, teachers play a fundamental role in procedure of grading, and assessment as an approach to teaching and learning that creates feedback is used to improve students' performance (Movahedi \& Aghajanzadeh Kiasi, 2021). However, teachers need proper assessment trainings that will assist them to perform their practice in the best way because teachers with limited assessment literacy skills who move through their teaching careers blindly and carelessly are more likely to harm the students' learning process (Benzehaf, 2017). Sound assessment practices are not like the kind of skills that a teacher typically acquires without support. Instead, they need solid trainings for subsequent professional development. Ertmer, Ottenbreitl-Leftwich, Sadik, Sendurur, and Sendurur (2012) argue that positive value beliefs towards innovative assessment should be fostered by educators' professional development programs, and they should be aware of innovative approaches to different models of assessment.

On the other hand, literature on teaching skills is rooted in the efforts to provide a basis to inspire developments in education in terms of policy and practice. These efforts involve both experimental studies and systematic reviews (Petty, 2006). Stronge (2007) identified five sets of key teaching skills that consider teacher as an individual, a classroom manager, an organizer for instruction, an implementer of instruction, and a teacher in teaching and monitoring students' progress. Marzano (2003) also identified three sets of key skills for teachers, namely strategies of instruction, classroom management, and curriculum design.

In addition, Horn and Staker (2012) also specify five skills which can facilitate work in small groups or one-on-one with students. The skills in this specification are teaching with comfort in chaos, analyzing students' learning and making decision accordingly, providing targeted learning opportunities to support students, having specialization due to differentiated roles of teachers, and possessing technological prowess for online teaching. High expectations, planning methods and strategies, pupil management, assessment methods, and homework control are the skills identified by McBer (2000) as important teaching skills.

EFL teachers need to be characterized on the basis of the subject they teach. They cannot simply present a set of procedures and methodology in their classrooms in order to achieve successful outcomes (Shojaei, Fazilatfar, \& Samavarchi, 2021). Effective teachers are notable by their commitment to the students and to their teaching career. They feel responsible for the students' achievement and success and endeavor to motivate, involve, and engage all students in learning avoiding the wrong concept that some students cannot be engaged and are predestined to do poorly. One of the bases of evidence on the skills of teaching lies in the materials that deal with the evaluation and 
performance of recognized teachers. These include the data from observation schedules of lessons in classrooms, and rating scales utilized to recognize the degree to which the skills were presented in the lessons (OECD, 2019).

All in all, all teachers should possess proper assessment strategies and teaching skills to implement an outcome-based teaching successfully. Teachers need to use various techniques in their teaching and assessment strategies even if they might not have received right pre-service or in-service trainings on given aspects of teaching and assessment (Tadesse, 2009). Besides, as Torrance and Pryor (2002) note, although teachers are familiar with a variety of teaching practices, they may lack a clear and strong outline for implementing the most suitable teaching and assessment strategies that would support students' learning. In addition, as Plok (2006) argues, teachers' assessment of their own students is one of the basic characteristics of effective teachers. However, it is unfortunate to say that teachers do not receive thorough training for augmenting pedagogical competence in issues related to the teaching skills and assessment strategies. Accordingly, research addressing teachers' teaching skills and assessment strategies in education is exceedingly desirable. These issues provide the rationale for the current study.

Teaching knowledge, skills, attitudes, and values have been taught and learned in combination across cultures and time (OECD, 2019). Schleicher (2019) notes that education is not just about teaching students something by itself; it is teaching them to develop a reliable road map and the mindset so as to find their own way in an increasingly complex world of today. According to Anil (2017), the teacher's personality, attitude, dexterously handling teaching materials, knack in answering students' questions, and ability to teach by using techniques instill interest among students. The real world of teaching and learning is ever evolving as the constantly changing relationship of teaching to learning and learning to teaching exists in a dynamic, symbiotic manner (Nouri \& Rahimy, 2020).

\section{Methodology}

\subsection{The Design of the Study}

The researchers used a questionnaire-based quantitative method. The design used in the current study can be considered as descriptive, since the researchers presented descriptions concerning naturally occurring phenomena connected with language development.

\subsection{Participants}

The participants in the present study consisted of 72 instructors practicing teaching in universities of Guilan Province. They were chosen based on convenience sampling as one of the main types of non-probability sampling methods. The participants were of both genders with a 25-65 age range with 5 to 25 years of teaching experiences and three fields of study namely, English Language Teaching, Linguistics, and English Language Literature. The participants also were of M.A. and Ph.D. holders.

\subsection{Instrument}

In order to implement the study, one copy of an already established questionnaire (Ghavidel \& Valipour, 2020) in terms of reliability and validity gained through EFA was adapted as the instrument in the present study. This questionnaire was used in order to know the degree of English language instructors' awareness of competences of assessment strategies and skills of teaching at Guilan universities. The questionnaire had 29 items and was in a Likert scale of 5 points, namely strongly agree, agree, neutral, disagree, and strongly disagree.

\subsection{Procedure}

Although the questionnaire used in the study was an already-standardized one as mentioned above, the validity and reliability of the questionnaire were estimated again. Saving the validity of the questionnaire, the researchers asked the experts in the field to consider the content and pinpoint the ambiguities or difficulties in wording by distributing the questionnaire among seven instructors practicing TEFL at Guilan universities. The questionnaire proved qualified since all instructors certified it as having very appropriate items supporting the factors. In order to pilot the questionnaire, it was administered to a sample representative of 20 experienced instructors at Rasht Islamic Azad and Guilan State Universities, due to the ease of access. The internal consistency of the questionnaire was estimated by Cronbach's alpha that proved to be .90 representing that the questionnaire was reliable for carrying out the study as the minimum recommended level of internal reliability is 70 (Nunnally \& Bernstein, cited in Panayides \& Walker, 2013). 


\subsection{Data Collection}

According to the outcomes of validity and reliability estimates of the questionnaire, the final version of the questionnaire included 29 items on teacher assessment strategies and teaching skills collectively out of the initial 36 items (see Appendix A). Next, the questionnaire was administered to 89 instructors through email. However, 72 questionnaires were submitted back to the researchers. Regarding the fact that the findings were based on answers given to the questions, descriptive data analyses (frequency table, average, percent...) and inferential analysis were conducted to see the differences in the instructors' competences of skills of teaching and assessment strategies through SPSS as data analysis tool.

\subsection{Data Analysis}

With regard to the fact that the findings were based on answers given to the questionnaire items, descriptive data analyses (frequency table, average, percent...) and inferential analysis (one-way ANOVA) were conducted to see the differences in the instructors' competences of skills of teaching and assessment strategies by the use of SPSS as data analysis tool.

\section{Results}

\subsection{Analysis of the Demographic Data}

Based on the data that the demographic section of the questionnaire yielded, the male $(65 \%)$ participants outnumbered the female (35\%) ones. Regarding the instructors' teaching experience, the instructors with 5-10 (16.6\%) years of teaching experience comprised the smallest group, and 32\% of the instructors fell within the 16-20 range of teaching experience that was the largest. Instructors in the field of English Language Teaching enjoyed the highest rank among other fields with 57\%. However, instructors in the field of Linguistics had the lowest rank (16.5\%). With regard to the instructors' degrees, Ph.D. holders were comparatively larger (73.5\%) than the M.A. holders that comprised $26.5 \%$ of the participants. The demographic data of the instructors are presented in Table 1 and Figure 1 below.

Table 1. The demographic information of the instructors

\begin{tabular}{lllll}
\hline & & Frequency & Percent & Valid percent \\
\hline Male & & 47 & 65 & 65 \\
Female & 25 & 35 & 35 \\
Teaching Exp. & $5-10$ & 12 & 16.6 & 16.6 \\
& $11-15$ & 19 & 26.3 & 26.3 \\
& $16-20$ & 23 & 32 & 32 \\
Field & $21-25$ & 18 & 25 & 25 \\
& E. L. Teaching & 41 & 57 & 57 \\
& E. Linguistics & 12 & 16.6 & 16.6 \\
Degree & E. L. Literature & 19 & 26.3 & 26.3 \\
& M. A. & 19 & 26.5 & 26.5 \\
& Ph.D. & 53 & 73.5 & 73.5 \\
\hline
\end{tabular}




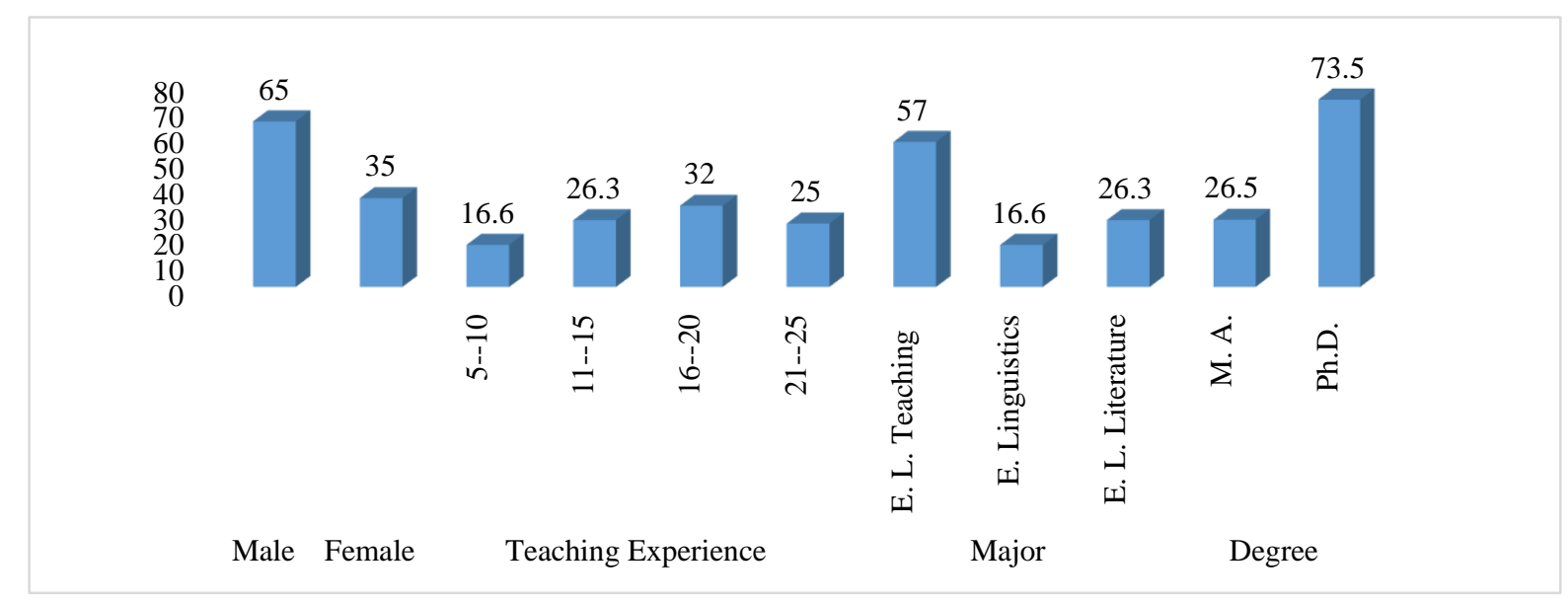

Figure 1. The demographic data of the participants in the second stage of the research

\subsection{Descriptive and Inferential Analysis of the Data}

The analysis depicts the status of instructors' personal, educational, and professional background with regard to their gender, years of teaching experience, fields of study, and university degrees. A one-way ANOVA was used to know whether there were any significant differences between the mean values of instructors' responses to the questionnaire items with regards to their personal and educational backgrounds mentioned above.

\subsubsection{Assessment Strategies and Gender}

The means and the standard deviations of the male and female instructors in response to the items of assessment strategies can be seen in Table 2 and Figure 2.

Table 2. The means and the standard deviations for the instructors' gender

\begin{tabular}{ccc}
\hline Gender & Mean & Standard deviation \\
\hline Men & 3.88 & 0.14 \\
Women & 3.12 & 0.26 \\
\hline
\end{tabular}




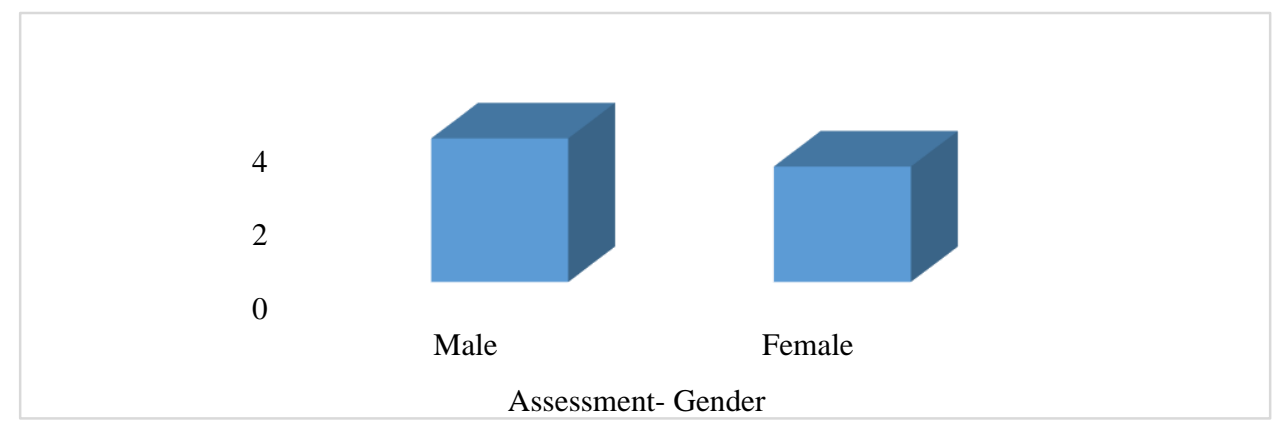

Figure 2. Asessment strategies and gender

According to the analysis, it was found that there existed a difference between instructors' gender and their awareness of assessment strategies. To examine this result inferentially, a variance analysis as shown in Table 3 was run.

Table 3. Variance analysis of assessment strategies and gender

\begin{tabular}{lccccc}
\hline $\begin{array}{c}\text { Source of } \\
\text { changes }\end{array}$ & $\begin{array}{c}\text { Degrees of } \\
\text { freedom }\end{array}$ & $\begin{array}{c}\text { Sum of } \\
\text { squares }\end{array}$ & $\begin{array}{c}\text { Mean of } \\
\text { square }\end{array}$ & Statistics & Probability value \\
\hline Gender & 1 & 1.083 & 0.083 & 1.540 & 0.222 \\
Error & 38 & 26.724 & 0.703 & & \\
Total & 39 & 27.807 & & & \\
\hline
\end{tabular}

According to the result, the F statistics (1.540) is bigger than the probability value (0.222). This means that there is a statistically significant difference between male and female instructors with regards to their awareness of assessment strategies at a significant level of $\alpha=\% 5$.

\subsubsection{Assessment Strategies and Teaching Experience}

Based on the descriptive analysis, the means and the standard deviations of the instructors with regard to their teaching experiences and their responses to the items of assessment strategies are displayed in Table 4 and Figure 3.

Table 4. The mean and the standard deviation for the instructors' teaching experiences

\begin{tabular}{ccc}
\hline Teaching experience & Mean & Standard deviation \\
\hline $5-10$ & 3.00 & 0.00 \\
$11-15$ & 4.82 & 0.29 \\
$16-20$ & 3.67 & 0.23 \\
$21-25$ & 4.21 & 0.11 \\
\hline
\end{tabular}




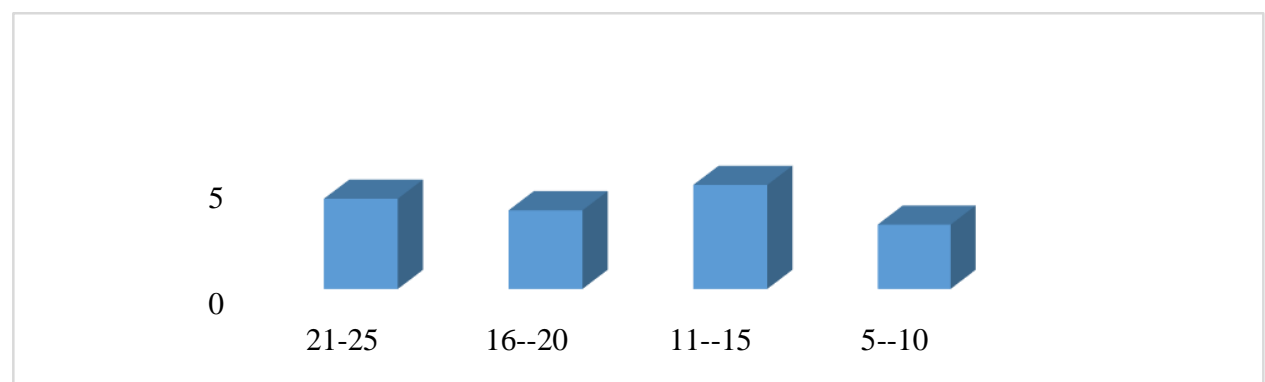

Figure 3. Assessment strategies and teaching experience

Based on result of ANOVA, it was found that there was a statistically significant difference between the instructors' teaching experience and their awareness of assessment strategies as shown in Table 5.

Table 5. Variance analysis of assessment strategies and teaching experience

\begin{tabular}{cccccc}
\hline Source of changes & $\begin{array}{c}\text { Degrees of } \\
\text { freedom }\end{array}$ & $\begin{array}{c}\text { sum of } \\
\text { squares }\end{array}$ & $\begin{array}{c}\text { Mean of } \\
\text { square }\end{array}$ & Statistics & Probability value \\
\hline Teaching experience & 4 & 7.634 & 1.909 & 3.311 & $* 0.021$ \\
Error & 35 & 20.173 & 0.576 & & \\
Total & 39 & 27.807 & & \\
\hline
\end{tabular}

Based on the result, since the F statistics (3.311) is bigger than the probability value of 0.021 , the assessment strategies used by teachers is different by their different years of teaching experiences at a significant level, $\alpha=\% 5$.

\subsubsection{Assessment Strategies and Fields of Study}

The means and the standard deviations of the instructors' responses to the questionnaire items regarding their awareness of assessment strategies related to their fields of study are shown in Table 6 and Figure 4.

Table 6. The means and the standard deviations for the instructors' fields of study

\begin{tabular}{lcc}
\hline \multicolumn{1}{c}{ Fields of study } & Mean & Standard deviation \\
\hline Teaching & 4.44 & 0.14 \\
Linguistics & 3.86 & 0.14 \\
Literature & 2.40 & 0.02 \\
\hline
\end{tabular}




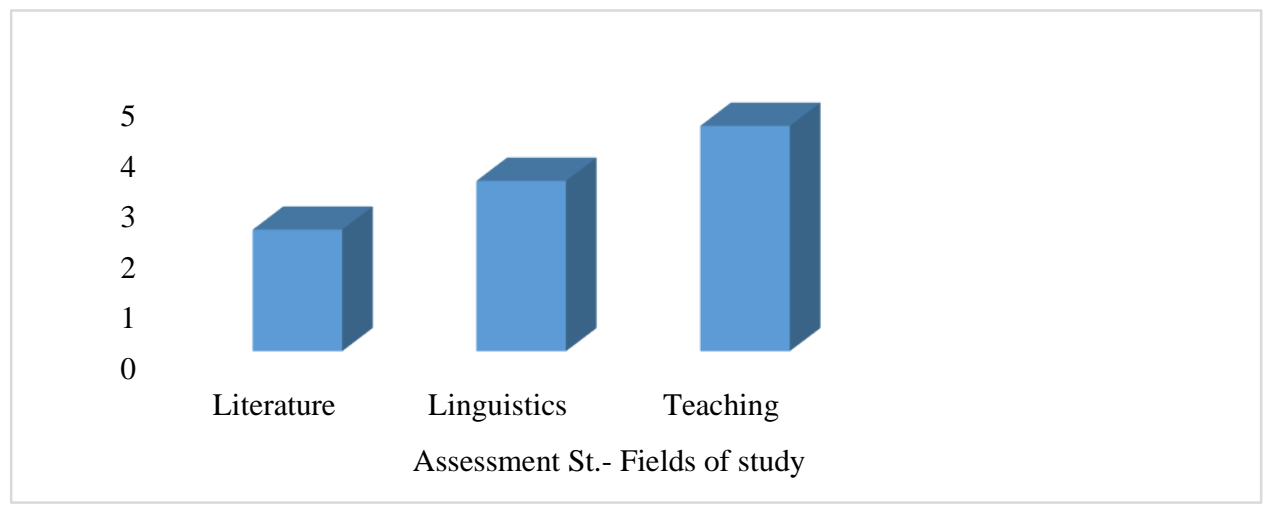

Figure 4. Assessment strategies and fields of study

The result of one-way ANOVA revealed a statistically significant difference between instructors' fields of study and their awareness of assessment strategies (Table 7).

Table 7. Variance analysis of assessment strategies and fields of study

\begin{tabular}{cccccc}
\hline $\begin{array}{c}\text { Source of } \\
\text { changes }\end{array}$ & $\begin{array}{c}\text { Degrees of } \\
\text { freedom }\end{array}$ & $\begin{array}{c}\text { Sum of } \\
\text { squares }\end{array}$ & $\begin{array}{c}\text { Mean of } \\
\text { square }\end{array}$ & Statistics & Probability value \\
\hline Fields & 3 & 12.056 & 4.019 & 9.184 & $* 0.000$ \\
Error & 36 & 12.751 & 0.438 & & \\
Total & 39 & 28.807 & & & \\
\hline
\end{tabular}

According to the results, as the probability value of 0.000 is smaller than the $\mathrm{F}$ statistics indicating that teachers of different fields of study owned different assessment strategies at a significant level $\alpha=\% 5$.

\subsubsection{Assessment Strategies and University Degrees}

Table 8 shows the means and the standard deviations of the instructors' responses to the items assessment strategies with regard to their university degrees.

Table 8 . The means and the standard deviations for the instructors' university degrees

\begin{tabular}{ccc}
\hline University degrees & Mean & Standard deviation \\
\hline M.A. & 2.49 & 0.14 \\
Ph.D. & 4.11 & 0.00 \\
\hline
\end{tabular}




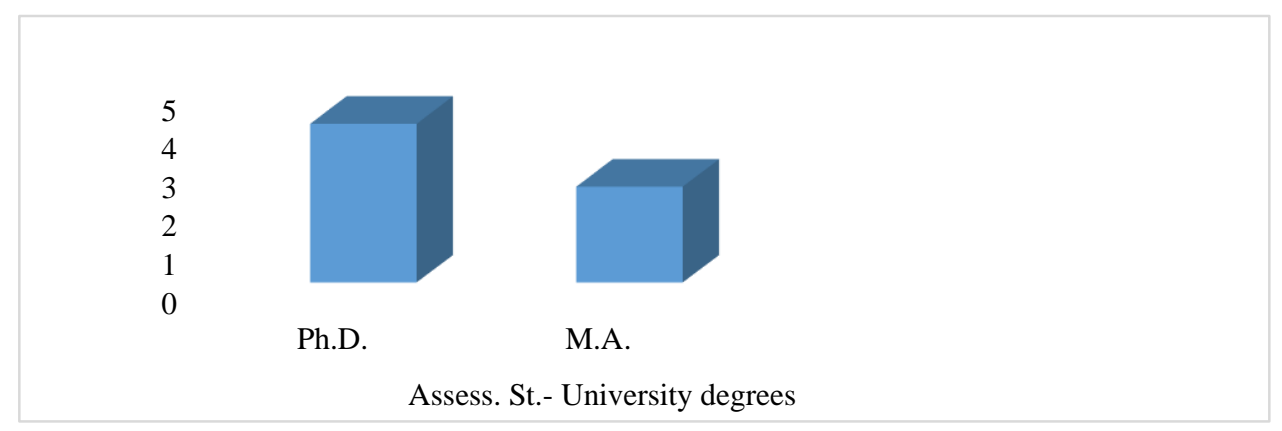

Figure 5. Assessment strategies and university degrees

To investigate the differences in assessment strategies inferentially regarding the instructors' responses to the items of assessment strategies, a one-way variance analysis was used as shown in Table 9.

Table 9. Variance analysis of assessment strategies and university degrees

\begin{tabular}{cccccc}
\hline $\begin{array}{c}\text { Source of } \\
\text { changes }\end{array}$ & $\begin{array}{c}\text { Degrees of } \\
\text { freedom }\end{array}$ & $\begin{array}{c}\text { Sum of } \\
\text { squares }\end{array}$ & $\begin{array}{c}\text { Mean of } \\
\text { square }\end{array}$ & Statistics & Probability value \\
\hline Degrees & 2 & 0.512 & 0.247 & & \\
Error & 36 & 7.895 & 0.216 & 1.260 & 0.418 \\
Total & 38 & 8.421 & & & \\
\hline
\end{tabular}

As the results shown in Table 9, the F statistics (1.260) is larger than the probability value that is 0.418 . This result indicated that assessment strategies employed by the instructors were statistically different according to their university degrees.

\subsubsection{Teaching Skills and Gender}

The means and the standard deviations of the instructors' responses to the items of teaching skills with regard to their gender differences can be seen in Table 10 and Figure 6.

Table 10. The means and the standard deviations for the instructors' gender

\begin{tabular}{ccc}
\hline Gender & Mean & Standard deviation \\
\hline Men & 4.53 & 0.10 \\
Women & 4.30 & 0.10 \\
\hline
\end{tabular}




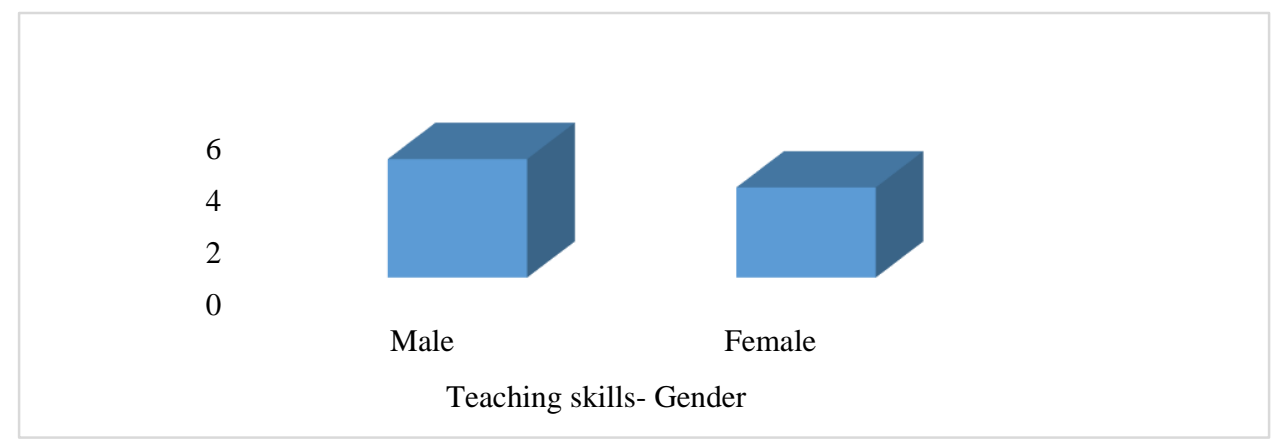

Figure 6. Teaching skills and gender

To investigate the gender differences inferentially regarding the instructors' responses to the teaching skills items, a one-way variance analysis was used as shown in Table 11.

Table 11. Variance analysis of teaching skill and gender

\begin{tabular}{cccccc}
\hline Source of changes & $\begin{array}{c}\text { Degrees of } \\
\text { freedom }\end{array}$ & $\begin{array}{c}\text { Sum of } \\
\text { squares }\end{array}$ & $\begin{array}{c}\text { Mean of } \\
\text { square }\end{array}$ & $\begin{array}{c}\text { Statistics } \\
\text { Probability } \\
\text { value }\end{array}$ \\
\hline Gender & 1 & 1.502 & 0.502 & & \\
Error & 38 & 8.609 & 8.609 & 2.216 & 0.145 \\
Total & 39 & 9.111 & & & \\
\hline
\end{tabular}

According to the analysis, the F statistics (2.216) is bigger than the probability value (0.145). This result indicated a statistically significant difference between male and female instructors in their teaching skills in a significant level, $\alpha=\% 5$.

\subsubsection{Teaching Skills and Teaching Experience}

According to Table 12, the means and the standard deviations of the instructors' responses in regard to their teaching experience and teaching skills are different.

Table 12. The means and the standard deviations for the instructors' teaching experience

\begin{tabular}{ccc}
\hline Teaching experiences & Mean & Standard deviation \\
\hline $5-10$ & 2.92 & 0.0 \\
$11-15$ & 3.41 & 0.16 \\
$16-20$ & 4.36 & 0.15 \\
$21-25$ & 3.12 & 0.09 \\
\hline
\end{tabular}




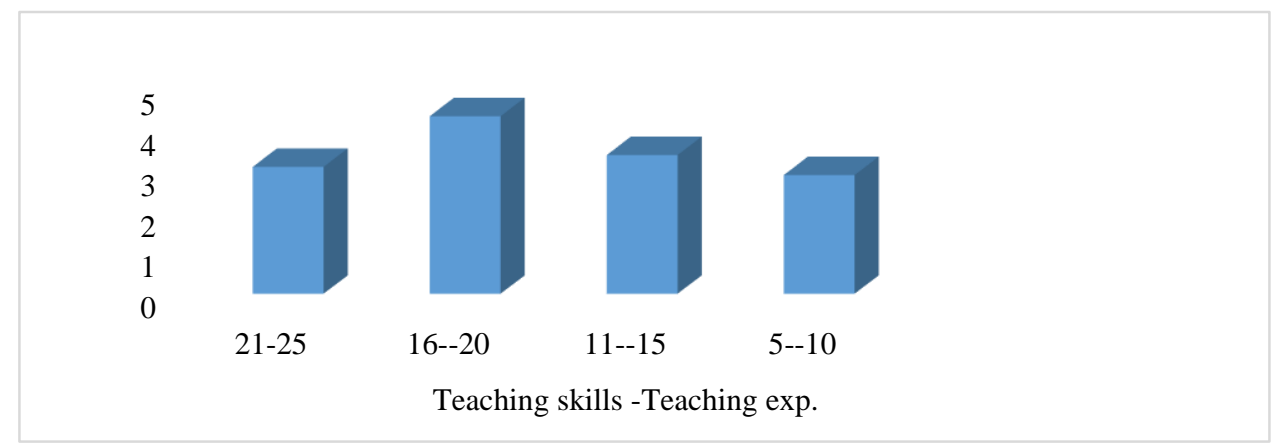

Figure 7. Teaching expereince and teaching skill

To investigate if there were a difference between instructors' teaching experiences and their teaching skill, a variance analysis was run as seen in Table 13.

Table 13. Variance analysis of teaching expereince and teaching skill

\begin{tabular}{cccccc}
\hline Source of changes & $\begin{array}{c}\text { Degrees of } \\
\text { freedom }\end{array}$ & $\begin{array}{c}\text { Sum of } \\
\text { squares }\end{array}$ & $\begin{array}{c}\text { Mean of } \\
\text { square }\end{array}$ & Statistics & $\begin{array}{c}\text { Probability } \\
\text { value }\end{array}$ \\
\hline Teaching experience & 4 & 1.596 & 0.399 & 1.859 & 0.140 \\
Error & 35 & 7.515 & 0.215 & & \\
Total & 39 & 9.111 & & & \\
\hline
\end{tabular}

According to the result, since the F statistics of 1.859 is greater than the probability value of 0.140 , teaching skill is statistically different according to the instructors' different years of teaching experience.

\subsubsection{Teaching Skills and Fields of Study}

Table 14 shows the means and the standard deviations of the responses given by the instructors to the items of teaching skills with regard to their years of teaching experience.

Table 14. The means and the standard deviations for the instructors' fields of study

\begin{tabular}{ccc}
\hline Fields & Mean & Standard deviation \\
\hline Teaching & 4.62 & 0.74 \\
Linguistics & 4.47 & 0.12 \\
Literature & 4.07 & 0.18 \\
\hline
\end{tabular}




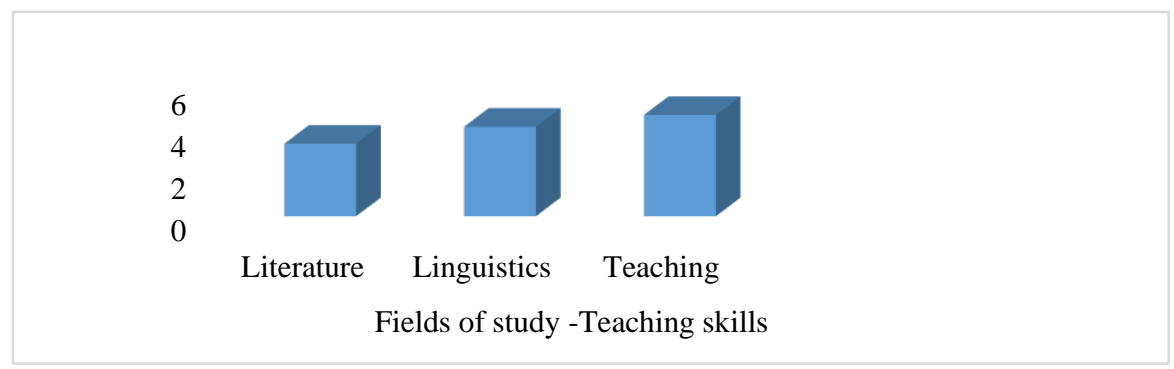

Figure 8. Teaching skills and fields of study

To explore the difference between instructors' fields of study and their teaching skill, a one-way ANOVA analysis was utilized (Table15).

Table 15. Variance analysis of instructors' fields of study and their teaching skill

\begin{tabular}{cccccc}
\hline $\begin{array}{c}\text { Source of } \\
\text { Changes }\end{array}$ & $\begin{array}{c}\text { Degrees of } \\
\text { freedom }\end{array}$ & $\begin{array}{c}\text { Sum of } \\
\text { squares }\end{array}$ & $\begin{array}{c}\text { Mean of } \\
\text { square }\end{array}$ & Statistics & Probability value \\
\hline Fields & 3 & 4.283 & 1.428 & & 0.000 \\
Error & 36 & 4.828 & 0.134 & 10.648 & \\
Total & 39 & 9.111 & & \\
\hline
\end{tabular}

As the Table 15 indicates, the F statistics (10.6480 is larger than the probability value, showing that at a significant level $\alpha=\% 5$, teaching experience is statistically different among the instructors with different fields of study.

4.2.8 Teaching Skills and University Degrees

As Table 16 shows, the means of the instructors' responses to items of teaching skills with regard to their university degrees are different.

Table 16. The means and the standard deviations of the instructors' university degrees

\begin{tabular}{ccc}
\hline University degree & Mean & Standard deviation \\
\hline M.A. & 2.25 & 0.15 \\
Ph.D. & 3.96 & 0.11 \\
\hline
\end{tabular}

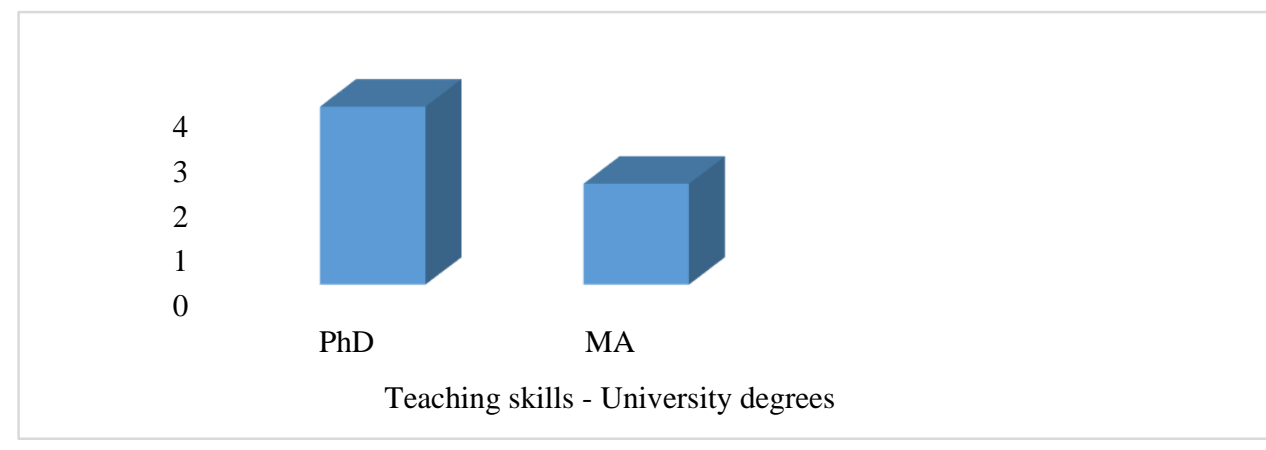

Figure 9. Teaching skills and university degrees 
To know the difference statistically between instructors' university degrees and their teaching skills, a one-way analysis of variance was used (Table 17).

Table 17. Variance analysis of teaching skills and university degrees

\begin{tabular}{|c|c|c|c|c|c|}
\hline $\begin{array}{l}\text { Source of } \\
\text { changes }\end{array}$ & $\begin{array}{l}\text { Degrees of } \\
\text { freedom }\end{array}$ & $\begin{array}{l}\text { Sum of } \\
\text { squares }\end{array}$ & $\begin{array}{c}\text { Mean of } \\
\text { square }\end{array}$ & Statistics & Probability value \\
\hline Degrees & 2 & 0.533 & 0.267 & & \\
\hline Error & 37 & 8.575 & 0.232 & 1.150 & 0.328 \\
\hline Total & 39 & 9.111 & & & \\
\hline
\end{tabular}

As the results show, the F statistics (1.150) is larger than the probability value that is 0.328 . This result indicated that teaching skills practiced by the instructors were statistically different according to their university degrees.

\section{Discussion}

It is truism that all instructors need to be equipped with assessment skills in order to effectively administer their assessment methods. It is clear that adopting alternative assessment methods and techniques is a challenging task for the instructors. Instructors need to take decisions on the methods/techniques so as to select and blend them. This ability according to Hounsell, $\mathrm{Xu}$, and Tai (2007) requires a thorough awareness of assessment practices and the way they influence learning and their understanding of the specific purposes and circumstances.

Regarding instructors' use of assessment strategies, it was found that the instructors used different assessment strategies with regard to their gender, teaching experience, fields of study, and university degrees. Similarly, it was found that the instructors of different educational backgrounds used various techniques in assessment as supported by Marso and Pigge (as cited in Tadesse 2009). As such, the study illustrated that that instructors' different assessment strategies and skills lie in their different personal and educational backgrounds.

It was also found that instructors with higher educational degrees try to overcome assessment challenges through various alternate solutions (Vongkulluksn, Xie, \& Bowman, 2018), and that the instructors' higher education inspired positive values towards assessment types that are innovative. Thus, instructors should develop awareness on promoting innovative approaches by adopting different assessment models (Ertmer et al., 2012).

Furthermore, it was found that the instructors were familiar with various types of assessment practices (e.g., cloze tests, performance assessments, etc.). Likewise, the finding of the current study in which the instructors of different backgrounds showed different assessment strategies, is in line with the finding of the study carried out by Yamtima and Wongwanichb (2014) who found that the participants in their study had a somewhat different levels of classroom assessment practices since they owned an ambiguous framework assessment implementations that did not reflect and support their student learning.

Moreover, the instructors' teaching skills were also different with regards to their gender, teaching experience, fields of study, and university degrees. Therefore, it can be concluded that the instructors' different professional and educational backgrounds resulted in different uses of assessment strategies and teaching skills in their teaching practice. As found in the current study, and according to Becher and Trowler (2001), the features of university disciplines in a university field play a vital role in the instructors' skills of teaching. Furthermore, the instructors' professional and educational features which might be derived from the teachers' university or professional background, may yield different experiential qualities (e.g., the performance of teachers, educational records, teaching experience, certificates, etc.) (Soodmand Afshar \& Hamzavi, 2017).

In line with findings of the current study that showed more experienced instructors enjoyed higher mean values compared to the teachers of lower teaching experience, Dhillon (2014) argues that teachers with well-established 
experiences provide well-structured lessons with clarity of purpose, convey high expectations, monitor progress, and provide intelligent feedback in a clear and fair discipline.

The outline for an innovative system may be blocked by various internal and external factors. Poor network infrastructure, lack of adequate resources (hardware \& software) and technical support (Lucas, 2018) are the external barriers at school or university levels. On the other side, the inside structure and the culture of an organization as internal blocks may act as demotivating factors since they may impose restrictions on an incentive system, which will hinder individuals from taking the necessary risk to innovate (Tierney, 2014).

\section{Conclusion}

In light of the findings of the current study, it seems indubitably imperative to carry out studies where all the pertinent constructs related to teaching practices are integrated concurrently. This would enable the researchers to specifically determine whether the pedagogical competences would precisely explain the quality of instruction that tries to leverage the potential of all the competences. Therefore, traditional methods cannot be written off from the classroom at any point of time, but including some of the interesting and innovating teaching methodologies and assessments strategies will make students be focused on the learning process. In general, teaching needs to emphasize areas such as planning and preparation, classroom organization, interactional skills, students' assessment and keeping portfolio, subject matter mastery all of which serve students' overall learning. Teachers' recognition of the capacities of pedagogical competences in teaching is of critical importance. The lack of this recognition causes anxiety and concern in them and hinders them from using pedagogical competences in their teaching practice. It is crystal clear that instructional competences potentially affect educational practice and experience. Therefore, raising a kind of awareness among university instructors on the extent of having incorporating their competences in teaching what they are supposed to impart to the students is of prime importance.

\subsection{Pedagogical Implications of the Study}

The implications of the study could be that the teachers need to be taught how the various knowledge factors could be treated as knowledge resources and the various pathways of synthesizing the basic and derived knowledge factors to achieve an effective teaching. When teacher educators draw upon the various constructs resources to create lessons for meaningful learning, they should make explicit the decision path and the rationale involved to the teachers. This is especially so for decisions involving the basic knowledge components. The results of the present research can also shed some light over the assessment mechanism of teacher recruitment and teacher on going profession of teaching.

\section{References}

Alquraan, M. F. (2012). Methods of assessing students' learning in higher education: Education, business and society. Contemporary Middle Eastern Issues, 5(2), 124-133. http://dx.doi.org/10.1108/17537981211251160

Anil, B. (2017). Applying innovative teaching methods in a second language classroom. International Journal of Research in English Education (IJREE), 2(2), 1-9. http://ijreeonline.com/article-1-55-en.html doi:10.18869/acadpub.ijree.2.2.1

Ávila, V. L., Filho, L. W., Brandli, L., Macgregor, C. J., Molthan-Hill, P., Özuyar, G. P., \& Martins, M. R. (2017). Barriers to innovation and sustainability at universities around the world. Journal of Cleaner Production, 164, 1268-1278. https://doi.org/10.1016/j.jclepro.2017.07.025

Ayua, G. A. (2017). Effective teaching strategies. Conference: Orientation and refresher workshop for teachers. Journal of Research in Curriculum and Teaching, 6(1), 459-465. https://doi.org/10.13140/RG.2.2.34147.09765

Bell, T. R. (2005). Behaviors and attitudes of effective foreign language teachers: Results of a questionnaire study. Foreign language Annals, 38(2), 259-270. https://doi.org/10.1111/j.1944-9720.2005.tb02490.x

Becher, T., \& Trowler, P. R. (2001). University tribes and territories ( $2^{\text {nd }}$ ed.). Buckingham: Open University Press.

Benzehaf, B. (2017). Exploring teachers' assessment practices and skills. International Journal of Assessment Tools in Education, 4(1), 1-18. https://doi.org/10.21449/ijate.254581

Bloxham, S., \& Boyd, P. (2007). Developing effective assessment in higher education practical guide. New York: Open University Press. 
Brečko, B. N., Kampylis, P., \& Punie, Y. (2014). Mainstreaming ICT - enabled innovation in education and training in Europe: Policy actions for sustainability, scalability and impact at system level. Luxembourg: Publications Office of the European Union.

Broadfoot, P., Timmis, S., Payton, S., Oldfield, A., \& Sutherland, R. (2013). Integrating the formative and summative through technology enhanced assessment. University of Bristol, Graduate School of Education.

Brookhart, S. M., \& Nitko, A. J. (2008). Assessment and grading in classrooms. Upper Saddle River, NJ: Pearson Prentice Hall.

Chen, R., Wu, Y., \& Liu, X. (2015). Chinese university students' perceptions of assessment tasks and classroom assessment environment. Language Testing in Asia, 5(13), 1-17. https://doi.org/10.1186/s40468-015-0020-6

Darling-Hammond, L. (2000). Studies of excellence in teacher education. Washington DC: American Association of Colleges for Teacher Education.

Dhillon, C. K. (2014). Identifying essential teaching skills. Scholarly Research Journal for Interdisciplinary Studies, 2(13), 13-20.

Ertmer, P. A., Ottenbreit-Leftwich, A. T., Sadik, O., Sendurur, E., \& Sendurur, P. (2012). Teacher beliefs and technology integration practices: A critical relationship. Computers \& Education, 59(2), $423-435$. https://doi.org/10.1016/j.compedu.2012.02.001

Feiman-Nemser, S. (2008). Teacher learning: How do teachers learn to teach? In M. Cochran-Smith, S. FeimanNemser, D. J. McIntyre, \& K. E. Demers (Eds.) Handbook of research on teacher education-enduring questions in changing contexts (pp. 697-705). London: Routledge

Fletcher, R. B., Meyer, L. H., Anderson, H., Johnston, P., \& Rees, M. (2012). Faculty and students conceptions of assessment in higher education. Journal of Higher Education, 64(1), 119-133. https://doi.org/10.1007/S10734-011-9484-1

Ghavidel, M., \& Valipour, V. (2020). The relationship between Iranian English language instructors' pedagogical competences and their personal and professional background. Iranian Journal of English for Academic Purposes, 9(4), 45-61.

Horn, M. B., \& Staker, H. (2012). Five skills for blended learning teachers. T.H.E. Journal. https://thejournal.com/articles/2012/10/04/5-skills-for-blended-learning-teachers.aspx

Hounsell, D., Xu, R., \& Tai, C. M. (2007). Enhancing practice: Integrative assessment, blending assignments and assessments for high-quality learning. Guide no 3. Gloucester: The Quality Assurance Agency for Higher Education.

Jay, M., \& O’Conner, K. (2005). Seven practices for effective learning. Educational Leadership, 63(3), $10-17$. https://www.ascd.org/el/articles/seven-practices-for-effective-learning

Khtou, H. (2011). Assessment in higher education: Students and teachers' perceptions. Saarbrucken: Lambert university publishing.

Lucas, M. (2018). External barriers affecting the successful implementation of mobile educational interventions. Computers in Human Behavior, 107(3), 1-7. https://doi.org/10.1016/j.chb.2018.05.001

Malikow, M. (2006). Effective teacher study. National Forum of Teacher Education Journal-Electronic, 16(3), 1-9. http://www.nationalforum.com/Electronic\%20Journal\%20Volumes/Malikow,\%20Max\%20Effective\%20te acher\%20Study.pdf

Marzano, R. J. (2003). What works in schools: Translating research into action. Alexandria, Virginia: Association for Supervision and Curriculum Development.

McBer, H. (2000). Research into teacher effectiveness: A model of teacher effectiveness. London: DfEE.

McLaughlin, M. W., \& Talbert, J. E. (2001). Professional communities and the work of high school teaching. Chicago, IL: University of Chicago Press. 
Melouk, M. (2001, March 25-29). The state of EFL evaluation in Morocco: The testers and teachers' opinions. In A. Zaki \& M. Naji, (Eds.). The teaching and assessment of English for global purposes. Paper presented at MATE proceedings, Essaouira (pp. 41-51). Rabat: MATE.

Movahedi, N., \& Aghajanzadeh Kiasi, G. (2021). The effect of teacher vs. learner-assessment activities on the Iranian intermediate EFL learners' writing ability. International Journal of Research in English Education (IJREE), 6(1), 49-63. http://ijreeonline.com/article-1-467-en.html

Nenty, H. J., Adedoyin, O., Odili, J. N., \& Major, T. E. (2007). Primary teacher's perceptions of classroom assessment practices as means of providing quality primary/basic education by Botswana and Nigeria. Educational $\begin{array}{llll}\text { Research } \quad \text { Review, } & \text { 2(4), }\end{array}$ https://academicjournals.org/article/article1379591342_Nenty\%20et\%20al.pdf

Nouri N., \& Rahimy, R. (2020). Hermeneutics of teacher education: An inclusion-based model. International Journal of Research in English Education (IJREE), 5(4), 101-112. http://ijreeonline.com/article-1-490-en.html doi: 10.29252/ijree.5.4.101

OECD (2019). Future of education and skills 2030: OECD learning compass 2030, a series of concept notes. OECD Publishing. https://www.oecd.org/education/2030-project/teaching-and-learning/learning/learning-compass2030/OECD_Learning_Compass_2030_Concept_Note_Series.pdf

Panayides, P., \& Walker, M. J. (2013). Evaluating the psychometric properties of the foreign language classroom anxiety scale for Cypriot senior high school EFL students: The Rasch measurement approach. Europe's Journal of Psychology, 9(3), 493-516. https://doi.org/10.5964/ejop.v9i3.611

Petty, G. (2006). Evidence-based teaching: A practical approach. Cheltenham: Nelson Thornes.

Plok, J. A. (2006). Traits of effective teachers. Arts Educational Policy Review, 107(4), 23-29. http://dx.doi.org/10.3200/AEPR.107.4.23-29

Popham, W. J. (2008). Classroom assessment: What teachers need to know (5 ${ }^{\text {th }}$ ed.). Boston: Pearson.

Ryegard, A., Apelgren, K., \& Olsson, T. (2010). A Swedish perspective on pedagogical competence. Stockholm: Uppsala University.

Schleicher, A. (2019). Presentation at the forum on transforming education: Global peace convention. Seoul, South Korea.

Shojaei, Z., Fazilatfar, A., \& Samavarchi, L. (2021). Exploring the characteristics of Iranian EFL teachers from the perspectives of educators, teachers and learners. International Journal of Research in English Education (IJREE), 6(2), 38-51. http://ijreeonline.com/article-1-504-en.html

Shukla, R. (2007). Dictionary of education. New Dehi: A.P.H. Publishing Corporation.

Smimou, K., \& Dahl, D. W. (2012). On the relationship between students' perceptions of teaching quality, methods of assessment, and satisfaction. Journal of Education for Business, 87(1), 22-35. https://doi.org/10.1080/08832323.2010.550339

Soga, O. (2000). Education. Keffi, Nasarawa State: National Teachers’ Institute.

Soodmand Afshar, H., \& Hamzavi, R. (2017). An investigation into the characteristics of Iranian EFL teachers of senior secondary schools and language institutes. Iranian Journal of Language Teaching Research, 5(1), 2136. https://doi.org/10.30466/IJLTR.2017.20340

Stronge, J. H. (2007). Qualities of effective teachers (2 ${ }^{\text {nd }}$ ed.). Alexandria, VA: Association of Supervision and Curriculum Development.

Tadesse, A. (2009). The status, gaps, and challenges of implementing continuous assessment: The case of second cycle primary schools in Debre Markos Town (MA Thesis). Addis Ababa University, Addis Aba.

Tierney, W. G. (2014). Creating a culture of innovation. The challenge in becoming and staying a world-class university. Pullias Center for Higher Education, Rossier School of Education, University of Southern California. 
Torrance, H., \& Pryor, J. (2002). Investigating formative assessment: Teaching, learning and assessment in the classroom. England: Open University Press.

Vongkulluksn, V. W., Xie, K., \& Bowman, M. A. (2018). The role of value on teachers' internalization of external barriers and externalization of personal beliefs for classroom technology integration. Computers \& Education, 118, 70-81. https://doi.org/10.1016/j.compedu.2017.11.009

Wilson, M., \& sloane, K. (2010). From principles to practice: An embedded assessment system. Applied Measurement in Education, 13(2), 181-208. https://doi.org/10.1207/S15324818AME1302_4

Yamtima, V., \& Wongwanichb, S. (2014). A study of classroom assessment literacy of primary school teachers. Procedia-Social and Behavioral Sciences, 116, 2998-3004. https://doi.org/10.1016/j.sbspro.2014.01.696

Zeichner, K., \& Liston, D. (1996). Reflective teaching: An introduction. Mahwah: Lawrence Erlbaum Associates. https://doi.org/10.4324/9780203822289 


\section{Appendix A}

\begin{tabular}{|c|c|c|c|c|c|}
\hline Items (variables) & $\begin{array}{l}\text { Strongl } \\
\text { y agree }\end{array}$ & Agree & Neutral & Disagree & Strongly disagree \\
\hline \multicolumn{6}{|l|}{$\begin{array}{l}\text { 1. I regularly provide feedback to students on their } \\
\text { performance. }\end{array}$} \\
\hline \multicolumn{6}{|l|}{$\begin{array}{l}\text { 2. I am able to organize a teaching-learning process } \\
\text { around language learning objectives. }\end{array}$} \\
\hline \multicolumn{6}{|l|}{ 3. I use technology to support language learning. } \\
\hline \multicolumn{6}{|l|}{$\begin{array}{l}\text { 4. I take part in the in-service training courses offered } \\
\text { by institution. }\end{array}$} \\
\hline \multicolumn{6}{|l|}{$\begin{array}{l}\text { 5. I update my English knowledge of subject matter } \\
\text { very often. }\end{array}$} \\
\hline \multicolumn{6}{|l|}{$\begin{array}{l}\text { 6. I encourage learners to monitor their own } \\
\text { performance. }\end{array}$} \\
\hline \multicolumn{6}{|l|}{$\begin{array}{l}\text { 7. I am able to demonstrate a sound English } \\
\text { knowledge while teaching the subject. }\end{array}$} \\
\hline \multicolumn{6}{|l|}{$\begin{array}{l}\text { 8. I am aware of various kinds of tests such as } \\
\text { diagnostic, achievement, and proficiency tests. }\end{array}$} \\
\hline \multicolumn{6}{|l|}{$\begin{array}{l}\text { 9. I help learners develop writing skill at different } \\
\text { proficiency levels. }\end{array}$} \\
\hline \multicolumn{6}{|l|}{$\begin{array}{l}\text { 10. I model self and peer-assessment techniques in the } \\
\text { class. }\end{array}$} \\
\hline \multicolumn{6}{|l|}{$\begin{array}{l}\text { 11. I own knowledge of the English language tasks and } \\
\text { exercise. }\end{array}$} \\
\hline \multicolumn{6}{|l|}{$\begin{array}{l}\text { 12. I have a plan to develop myself based on my needs } \\
\text { and interests. }\end{array}$} \\
\hline \multicolumn{6}{|l|}{$\begin{array}{l}\text { 13. I have various strategies of developing my } \\
\text { understanding of English grammar \& vocabulary. }\end{array}$} \\
\hline \multicolumn{6}{|l|}{$\begin{array}{l}\text { 14. I have critical attitudes to my own teaching } \\
\text { (examining, discussing, questioning practices). }\end{array}$} \\
\hline \multicolumn{6}{|l|}{$\begin{array}{l}\text { 15. I am able to assess learners' knowledge of } \\
\text { language components; i.e. grammar, } \\
\text { pronunciation, and vocabulary. }\end{array}$} \\
\hline \multicolumn{6}{|l|}{ 16. I have sufficient knowledge about English. } \\
\hline \multicolumn{6}{|l|}{ 17. I plan, manage, and coordinate my teaching. } \\
\hline \multicolumn{6}{|l|}{$\begin{array}{l}\text { 18. I make students familiar with basis of critical } \\
\text { thinking in order to enable them make appropriate } \\
\text { decisions regarding absorbing or rejecting target } \\
\text { cultural norms. }\end{array}$} \\
\hline $\begin{array}{l}\text { 19. I study the latest research papers and use their } \\
\text { findings in my teaching. }\end{array}$ & & & & & \\
\hline
\end{tabular}




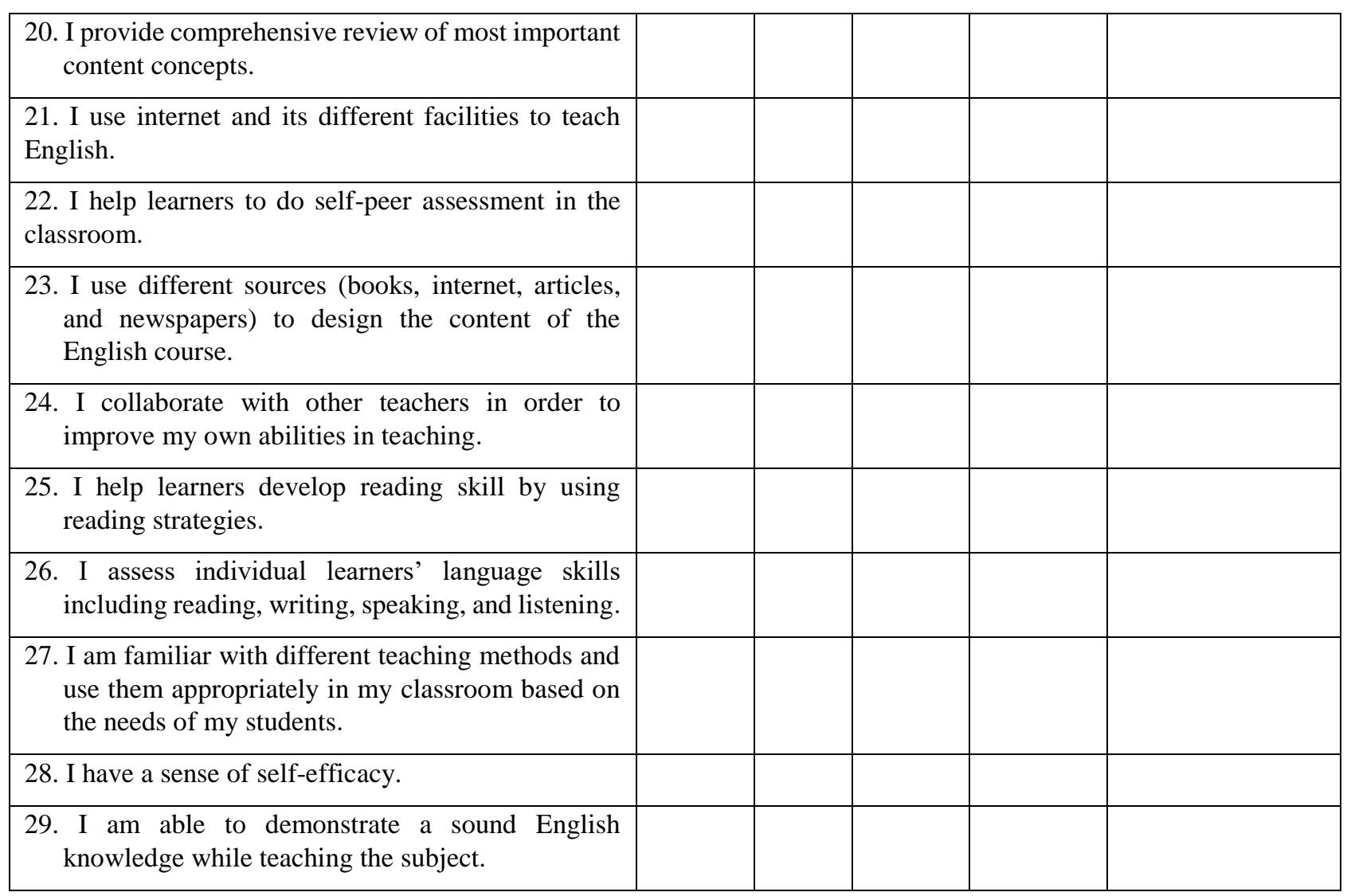

